\title{
Sintesis dan Uji Aktivitas Senyawa 1-Benzil-3-benzoilurea Tersubstitusi Bromo, Kloro, Floro dan Triflorometil pada posisi para sebagai Agen Antiproliferatif
}

\author{
Farida Suhud', Siswandono², Tutuk Budiati² \\ ' Laboratorium Kimia Farmasi, Fakultas Farmasi Universitas Surabaya, Surabaya \\ ${ }^{2}$ Fakultas Farmasi Universitas Airlangga, Surabaya \\ Korespondensi: Farida Suhud \\ Email: faridasuhud@staff.ubaya.ac.id
}

\begin{abstract}
ABSTRAK: Sintesis dan uji aktivitas 1-benzil-3-benzoilurea tersubstitusi $\mathrm{F}, \mathrm{Cl}, \mathrm{Br}$ dan $\mathrm{CF}_{3}$ pada posisi para sebagai agen antiproliferatif telah dilakukan. Tujuan dari studi ini untuk membandingkan aktivitas sebagai agen antiproliferatif senyawa 1-benzil-3-benzoilurea dengan substituen golongan halogen. Untuk mencapai tujuan tersebut uji aktivitas secara in-silico terhadap reseptor 1-UWH diprediksi dengan Molegro Virtual Docker (MVD) 5 dan hidroksiurea digunakan sebagai pembanding. Selanjutnya uji aktivitas secara in-vitro terhadap kultur sel MCF-7 dilakukan dengan MTT-assay. Hasil didapatkan senyawa 1-benzil-3-(4-CF -benzoil)urea lebih poten dibandingkan yang lain. Sangat direkomendasikan untuk dilakukan prediksi bioavailabilitas dan toksisitas serta uji lebih lanjut senyawa 1-benzil-3-(4 $\mathrm{CF}_{3}$-benzoil)urea sebagai calon obat dengan aktivitas antiproliferatif.
\end{abstract}

Kata kunci: atenolol; sintesis; uji aktivitas in-silico; uji aktivitas in-vitro; 1-benzil-3-benzoilurea; antiproliferatif

\begin{abstract}
Synthesis and activity test towards 1 benzoyl-3-benzylurea substituted with $\mathrm{F}, \mathrm{Cl}, \mathrm{Br}$ and $\mathrm{CF}_{3}$ in para position as an antiproliferative agent has been done. The purpose of this study is to compare the activity of 1-benzoyl-3-benzylurea compound with halogen group substituent as an antiproliferative agent. In order to reach such purpose, an in-silico activity test towards 1-UWH receptor predicted with Molegro Virtual Docker (MVD) 5 and hydroxyurea was used as a reference. Further, an in-vitro activity test towards MCF-7 cell line has been done with MTT-assay. The result shows that 1-(4 CF $F_{3}$-benzoyl)3-benzylurea compound is more potent than the others. It is highly recommended to do bioavailability and toxicity predictions, and further test towards 1-(4 CF -benzoyl)-3- benzylurea as a prospective future medicine with antiproliferative activity.
\end{abstract}

Keywords: synthesis; in-silico activity test; in-vitro activity test; 1 benzoyl-3-benzylurea; antiproliferative 


\section{Pendahuluan}

Kanker merupakan salah satu penyakit tidak menular yang telah menjadi masalah kesehatan di dunia, termasuk di Indonesia. Data Badan Kesehatan Dunia (WHO) tahun 2013 menunjukkan kanker merupakan penyebab kematian nomor 2 setelah penyakit kardiovaskuler. Insiden kasus kanker meningkat dari 12,7 juta menjadi 14,1 juta antara tahun 2008- 2012, diikuti dengan peningkatan angka kematian dari 7,6 juta tahun 2008 menjadi 8,2 juta tahun 2012. Berdasarkan Riset Kesehatan Dasar (Riskesdas) oleh litbang Depkes RI tahun 2007, kanker menempati urutan ke 6 penyebab kematian terbesar di Indonesia. Berdasarkan Riskesdas 2013, kanker dapat menyerang semua kelompok umur, masyarakat miskin dan kaya dan semua strata pendidikan. Angka nasional kanker adalah 1,4 per 1000 penduduk, dengan angka kejadian lebih tinggi pada perempuan: 5,7 per 1000 penduduk, dibandingkan dengan laki-laki: 2,9 per 1000 penduduk. Data dari Sistim Informasi Rumah Sakit (SIRS) menunjukkan, kanker payudara $(28,7 \%)$ menduduki urutan pertama insiden kanker. Menurut Globocan estimation, International Agency for Research on Cancer (IARC) year 2012, insiden kanker payudara 40 per 100.000 wanita. Diperkirakan pada tahun 2030, 26 juta penduduk dunia akan menderita kanker dan 17 juta akan meninggal, terutama mereka yang di negara berkembang. Untuk mengendalikan kanker, Kementerian Kesehatan telah melakukan upaya melalui pendekatan pengendalian faktor risiko dan deteksi dini. Selain itu, dilakukan upaya pengobatan di rumah sakit dan pelayanan paliatif. Namun semua upaya tersebut tidak akan maksimal dan tidak akan berhasil tanpa dukungan semua sektor terkait, beserta seluruh lapisan masyarakat.

Untuk mendukung upaya tersebut dilakukan sintesis dan uji aktivitas senyawa 1-benzil3-benzoilurea tersubstitusi bromo, kloro, fluoro dan trifluorometil pada posisi para sebagai agen antiproliferatif. Suhud et al. [1] telah membuktikan senyawa induk 1-benzil-3-benzoilurea mempunyai aktivitas in-silico terhadap reseptor dengan kode PDB 1-UWH dan in-vitro sebagai antiproliferatif terhadap kultur sel kanker payudara MCF-7 lebih tinggi dibanding hidroksiurea (senyawa yang sudah terbukti secara klinis sebagai antikanker). RS (Rerank Score) 1-benzil3-benzoilurea -90,5615 kkal/mol dan hidroksiurea $-23,553 \mathrm{kkal} / \mathrm{mol}$,sedangkan IC $_{50}$ (Inhibitory Concentration $50 \%$ ) berturut-turut $384,57 \mu \mathrm{M}$ dan $1228,96 \mu \mathrm{M}$. RS yang semakin negatif memiliki arti bahwa energi yang diperlukan untuk interaksi obat-reseptor semakin kecil sehingga ikatan obat-reseptor lebih stabil dan diprediksi aktivitasnya meningkat $[2,3]$.

Oleh karena itu penelitian dilanjutkan dengan modifikasi struktur senyawa induk berdasarkan teori bahwa aktivitas biologis suatu senyawa dipengaruhi oleh sifat fisikokimia, yang dapat dikelompokkan menjadi tiga yaitu sifat lipofilik, elektronik dan sterik. Sifat lipofilik mempengaruhi kemampuan senyawa dalam menembus membran biologis, sifat elektronik terutama mempengaruhi proses interaksi obat-reseptor dan juga mempengaruhi penembusan membran biologis, sedang sifat sterik menentukan keserasian interaksi molekul senyawa dengan reseptor dalam sel $[4,5]$. Substituen dipilih atas pertimbangan sifat lipofilik, elektronik dan sterik yang berpengaruh pada aktivitas. Pereaksi yang digunakan adalah benzilurea dan benzoil klorida dipilih tersubstitusi halogen $\mathrm{Br}, \mathrm{Cl}, \mathrm{F}, \mathrm{CF}_{3}$ pada posisi para. Atom $\mathrm{Cl}$ mempunyai nilai $(++) \pi$ dan $(++) \sigma$, interpretasi yang sederhana adalah peningkatan aktivitas disebabkan oleh peningkatan sifat lipofilik dan elektronik. Selanjutnya pilihan pada substituen $4-\mathrm{Br}, 4-\mathrm{CF}_{3}$ yang mempunyai nilai $(+++) \pi$ dan nilai $(+++) \sigma$, dan $4-F$ yang mempunyai nilai $(+)$ $\pi$ dan nilai $(+) \sigma$. Semua substituen ini akan diamati pengaruh masing-masing terhadap aktivitas [6]. Modifikasi struktur dilanjutkan dengan sintesis.

Penelitian terdahulu turunan urea yang sudah dilakukan Li et al. [7], sintesis 24 turunan 1,3-disubstitusi urea menggunakan reaksi kondensasi aldehida dengan amina bervariasi yang me- 
ngandung gugus fungsi (farmakofor) dan mudah didapat di pasaran. Lokwani [8] melakukan sintesis 2 tahap, pertama sintesis amina sekunder dari aldehida, tahap selanjutnya sintesis turunan benzilurea. Hardjono [9] melakukan sintesis turunan 1-(benzoiloksi) urea dengan metode SchottenBaumann yang dimodifikasi, yang menggunakan trietilamin ataupun piridin yang bereaksi dengan asam klorida yang terbentuk dan mencegahnya dari penyebab reaksi samping. Reaksi umumnya dilakukan pada suhu kamar atau suhu yang lebih rendah untuk mendapatkan hasil. Proses kerja metode ini sederhana, cepat dan hasil sintesis berkisar 10,40- 59,50\%.

Dengan mengacu pada metode Schotten-Bauman yang dimodifikasi [10], dalam penelitian ini dilakukan sintesis sebagai berikut benzilurea dicampur dengan tetrahidrofuran dan trietilamin. Reaksi antara benzilurea dan benzoil klorida tersubstitusi menggunakan reaksi substitusi nukleofilik dengan metode Schotten-Baumann yang dimodifikasi dapat dilihat pada Gambar 1.
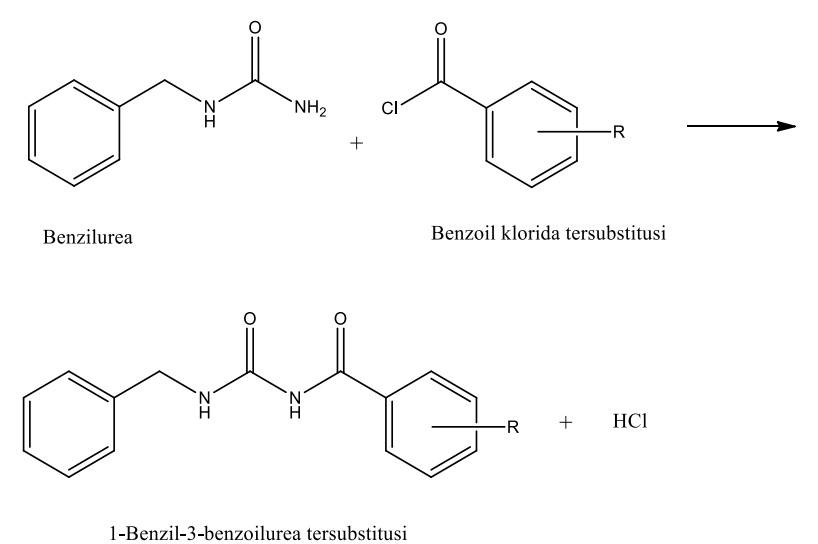

Gambar 1. Reaksi benzilurea dan benzoil klorida tersubstitusi

Prediksi interaksi gugus farmakofor dengan reseptor diamati dengan uji in silico, sehingga dapat diprediksi aktivitas senyawa hasil rancangan. Aktivitas ditunjukkan dengan harga energi ikatan senyawa dengan reseptor, yang dinyatakan dalam nilai Rerank Score. Makin kecil harga energi ikatan menunjukkan ikatan yang dihasilkan makin stabil, sehingga diprediksi aktivitasnya semakin besar [2, 3]. Uji in silico adalah istilah untuk percobaan atau uji melalui simulasi yang dilakukan dengan media komputer. Uji in silico dilakukan dengan melakukan penambatan molekul calon obat dengan reseptor terpilih. Penambatan dilakukan untuk menyelaraskan molekul calon obat (ligan $=$ molekul kecil) ke dalam reseptor yang merupakan molekul besar protein, dengan memperhatikan sifat keduanya [11]. Reseptor yang dipilih untuk penambatan senyawa turunan 1-benzil-3-benzoilurea adalah Protein Kinases atas dasar penelitian Li et al. [7].

Dari penelusuran pustaka Protein Data Bank berdasarkan kemiripan struktur dengan senyawa yang sudah diidentifikasi, 1-benzil-3-benzoilurea sesuai untuk berinteraksi dengan reseptor PTKs (Protein Kinases) yaitu RAF (Rapidly Accelerated Fibrosarcoma) kinases dengan kode 1 UWH dan berperan sebagai inhibitor. PTKs saat ini sangat intensif diinvestigasi, karena perannya dalam jalur transduksi sinyal proliferatif pada sel-sel mamalia. Banyak reseptor-reseptor faktor pertumbuhan trans membran melalui aktivitas inisiasi PTKs intraselular, selanjutnya ikatan eksternal dari faktor pertumbuhan akan menjadi tahap pertama jalur transduksi sinyal seluler yang mengatur mitogenesis dan proliferasi sel.

Uji in vitro aktivitas antikanker sebagai antiproliferatif menggunakan teknologi kultur sel kanker payudara MCF-7 (Michigan Cancer Foundation-7) dilakukan dengan metode MTT-assay (3[4,5-dimetiltiazol-2-il]-2,5-difeniltetrazolium bromida). Nilai $\mathrm{IC}_{50}$ yang didapat menggambarkan konsentrasi yang dapat menghambat 50\% proses proliferasi sel kanker. Dipilih MCF-7, karena merupakan kultur sel yang digunakan secara luas serta memiliki karakteristik tumor primer dan jalur fosforilasi ERK mudah dideteksi dalam kultur sel ini (http://www.tgrbio.com/cancercell-lines-primary-cell-cultures/cell-modelsmcf7-cells.html). Jalur fosforilasi ERK ini terkait erat dengan proliferasi dan senyawa yang diteliti bekerja sebagai penghambat pada jalur ini. Penelitian yang sudah dilakukan oleh Li et al. [7], Lokwani et al. [8], El-Sawy et al. [12], dan Dwitaharyani [13] juga menggunakan kultur sel MCF-7 
untuk uji aktivitas antiproliferasi pada kanker payudara dan survei yang menyatakan bahwa sebagian besar penelitian antikanker pada kanker payudara menggunakan kultur sel MCF-7. Pemilihan uji aktivitas pada kanker payudara karena kanker tersebut di Indonesia menempati urutan pertama penyebab kematian karena kanker pada wanita (www.depkes.go.id). Aktivitas dinyatakan dengan $\mathrm{IC}_{50}$ [14] dihitung dengan analisis probit.

Diharapkan modifikasi struktur 1-benzil3-benzoilurea tersubstitusi akan menghasilkan senyawa sintetis yang murni dengan aktivitas insilico dan in vitro sebagai antikanker lebih tinggi dibanding hidroksiurea.

\section{Metode}

Penelitian yang akan dilakukan adalah penelitian eksperimental laboratorium terhadap aktivitas antikanker senyawa 1-benzil-3-benzoilurea tersubstitusi, yang terdiri dari: 1) uji aktivitas in silico, 2) sintesis, dan 3) uji aktivitas in-vitro.

\subsection{Uji in silico aktivitas 1-benzil-3-benzoilurea tersubtitusi}

Uji in silico terhadap hidroksiurea (pembanding), 1-benzil-3-benzoilurea induk dan tersubstitusi ditentukan dengan cara melakukan penambatan senyawa tersebut pada reseptor PTKs yaitu RAF kinases yang digambarkan dengan kode I-UWH.

\subsection{Sintesis 1-benzil-3-benzoilurea tersubstitusi}

Sintesis 1-benzil-3-benzoilurea tersubstitusi mengacu pada metode Schotten-Bauman yang dimodifikasi [10] dilakukan dengan senyawa awal benzilurea. Pengambilan benzilurea dilakukan dengan menimbang bahan setara dengan 0,025 mol. Pereaksi benzoil klorida tersubstitusi sangat reaktif, pengambilan dilakukan dengan pipet, dan dilakukan dengan hati-hati di dalam lemari asam sedang untuk yang padatan ditimbang setara dengan 0,0275 mol. Pada hasil sintesis kemudian dilakukan: 1) pengamatan organoleptis, 2) pengujian kemurnian, dan 3) penentuan struktur.

\subsection{Uji in-vitro aktivitas senyawa 1-benzil-3-ben- zoilurea tersubstusi}

Untuk uji aktivitas desainnya dibagi menjadi: 1) pengaturan dosis, dan 2) pemaparan pada sel kanker.

\subsubsection{Desain pengaturan dosis senyawa hasil sintesis dan pembanding}

Pengaturan dosis senyawa hasil sintesis, pembanding didesain seperti pada Gambar 4.3. Kelompok hasil sintesis 1-benzil-3-benzoilurea induk dan tersubstitusi maupun kelompok pembanding yaitu hidroksiurea, dibuat dalam larutan baku induk $5000 \mu \mathrm{g} / \mathrm{mL}$. Setelah dilakukan pengenceran sesuai prosedur kerja akan didapatkan 6 (enam) dosis yaitu: 250; 125; 62,5; 31,25; 15,625 dan 7,8125 $\mu \mathrm{g} / \mathrm{mL}$.

\subsubsection{Desain kontrol pelarut}

Kontrol pelarut dimaksudkan untuk melihat pengaruh pelarut terhadap matinya sel kanker, karena beberapa pelarut termasuk DMSO, dapat menyebabkan kematian sel kanker. Volume pelarut disesuaikan dengan volume yang digunakan untuk melarutkan senyawa.

\subsubsection{Desain kontrol media}

Kontrol media dimaksudkan untuk melihat pengaruh media terhadap reaksinya dengan MTT.

\subsubsection{Desain pemaparan pada sel kanker}

Pemaparan pada sel kanker didesain seperti pada Gambar 2.

\section{Hasil dan pembahasan}

\subsection{Uji in silico terhadap reseptor RAF kinases}

Hasil uji in silico dimaksudkan untuk melihat jenis asam amino serta nilai energi ikatan antara hidroksiurea sebagai senyawa pembanding (HU) dan senyawa 1-benzil-3-benzoilurea tersubstitusi (4-X BBU) dengan reseptor RAF kinases (kode: 1-UWH). Gambaran tiga dimensi ikatan hidrogen yang terlibat dalam interaksi dengan reseptor RAF kinases (kode: 1-UWH) dapat dilihat pada Gambar 3 dan Tabel 1. 


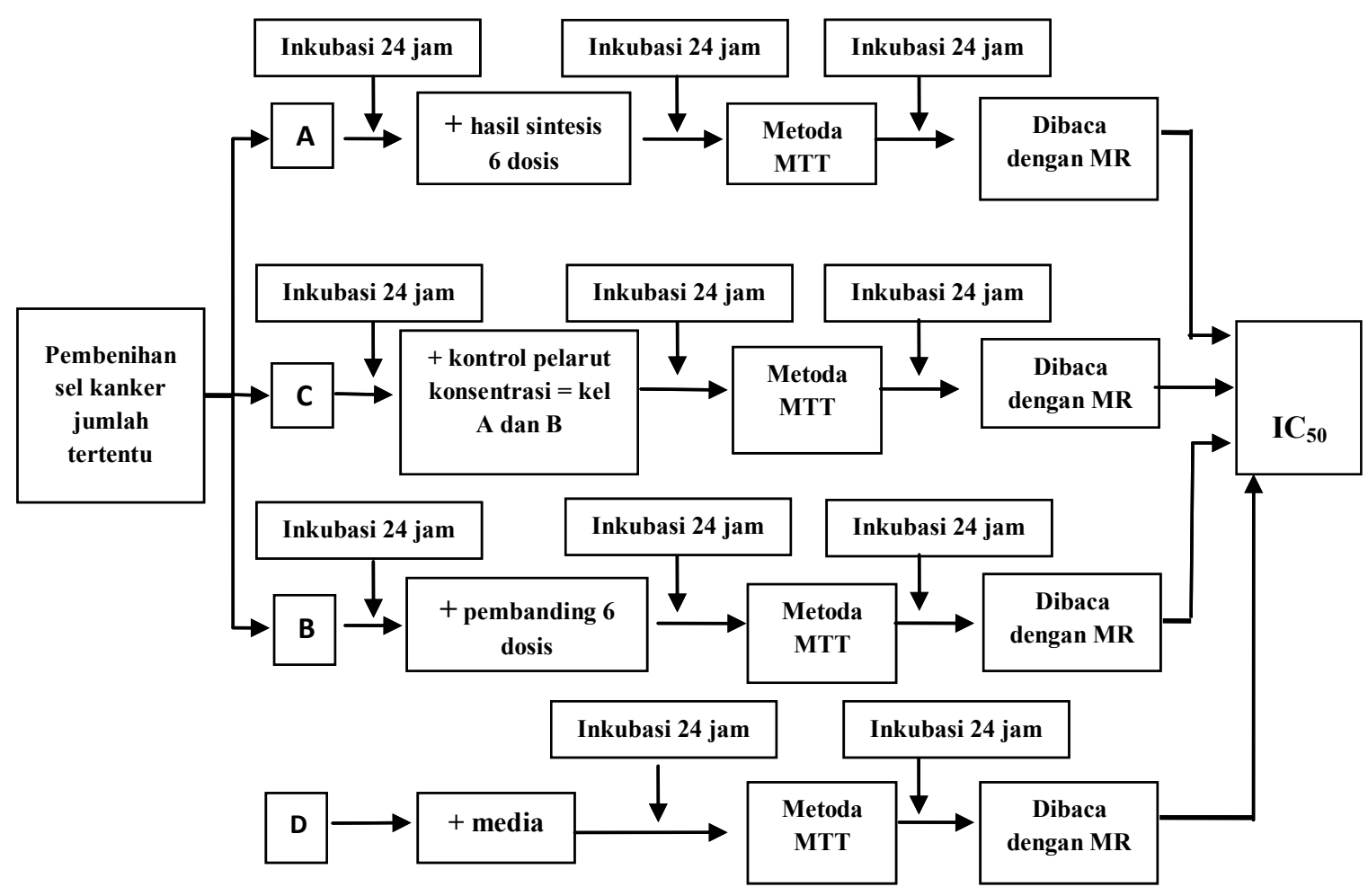

Gambar 2. Desain uji aktivitas in-vitro senyawa hasil sintesis dan pembanding

Keterangan: tiap pemaparan dilakukan replikasi tiga kali

- A adalah kelompok hasil sintesis

- B adalah kelompok pembanding

- C adalah kelompok kontrol pelarut

- D adalah kelompok kontrol media (tanpa sel kanker)

- MR adalah Microplate Reader

Tabel 1. Ikatan hidrogen dan asam-asam amino yang terlibat dalam interaksi antara senyawa pembanding $\mathrm{HU}$ dan 4-X BBU terhadap reseptor 1-UWH

\begin{tabular}{llll}
\hline No. & Nama senyawa & Glu 500 & Asp 593 \\
\hline 1. & Hidroksiurea & + & + \\
2. & $4-\mathrm{Cl} \mathrm{BBU}$ & + & + \\
3. & $4-\mathrm{Br} \mathrm{BBU}$ & + & + \\
4. & $4-\mathrm{F} \mathrm{BBU}$ & + & + \\
5. & $14-\mathrm{CF}_{3} \mathrm{BBU}$ & + & + \\
\hline
\end{tabular}

Pada Tabel 1, baik senyawa pembanding maupun senyawa tersubstitusi berinteraksi melalui ikatan hidrogen dengan pola yang sama dari gugus yang sama dengan asam amino Glu500 dan Asp593, ini membuktikan gugus urea merupakan farmakofor untuk aktivitas anti kanker. Untuk mengetahui asam-asam amino yang terlibat pada proses interaksi obat-reseptor dengan gugus farmakofor yang lain dan gugus haptofor dapat dilihat dari gambaran interaksi sterik senyawa dan reseptor. Senyawa-senyawa tersubstitusi berinteraksi sterik dengan pola yang sama dari gugus yang sama yaitu gugus benzil dengan asam amino Lys482, Thr528, Ile526 dan Glu500. Hal ini membuktikan gugus benzil juga merupakan farmakofor untuk aktivitas anti kanker. Asam-asam amino yang terlibat dalam interaksi sterik senyawa pembanding dan senyawa 1-benzil-3-benzoilurea tersubstitus dapat dilihat pada Tabel 2 .

Ukuran kekuatan energi ikatan obat-reseptor ditunjukkan oleh nilai rerank score (RS). Rerank Score adalah nilai yang didapatkan setelah reranking dan merupakan kombinasi linier MolDock Score dengan energi dari ikatan hidrogen serta ikatan VDW [15].

Semakin kecil nilai RS menunjukan semakin stabil ikatannya, diprediksi aktivitasnya juga semakin tinggi. Data dapat dilihat pada Tabel 3. 


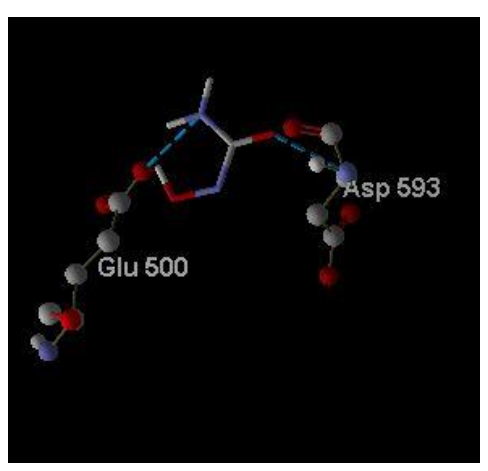

a

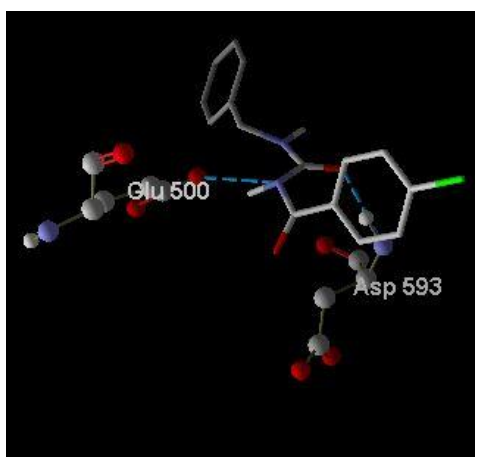

b

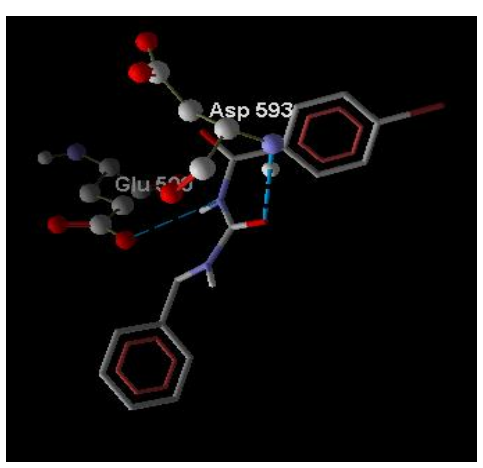

C

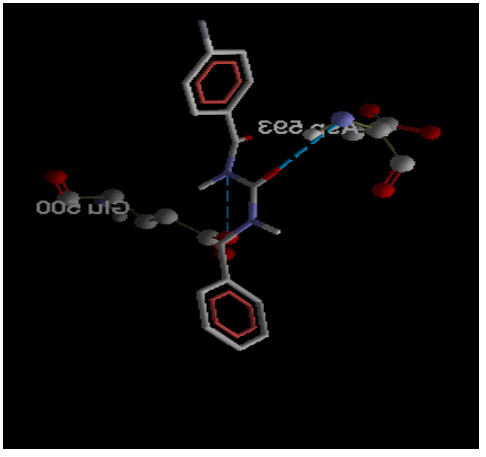

d

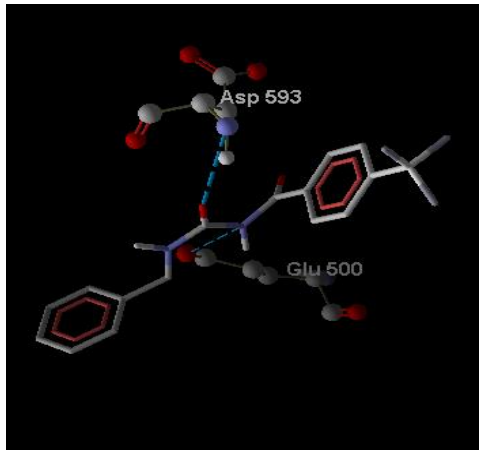

e

Gambar 3. Ikatan hidrogen dan asam-asam amino yang terlibat dalam interaksi antara senyawa HU dan 4-X BBU terhadap reseptor 1-UWH. a. HU, b. 4-Cl BBU, c. 4-Br BBU, d. 4-F BBU, e. 4-CF 3 BBU

Tabel 2. Interaksi sterik dan asam-asam amino yang terlibat dalam interaksi antara HU dan4-X BBU terhadap 1- UWH

\begin{tabular}{lllllllllllllll}
\hline No & Senyawa & Glu & Asp & Ile & Leu & Phe & Thr & Gly & Ile & Lys & Leu & Ile & Leu & Val \\
& & $\mathbf{5 0 0}$ & $\mathbf{5 9 3}$ & $\mathbf{5 9 1}$ & $\mathbf{5 0 4}$ & $\mathbf{5 9 4}$ & $\mathbf{5 2 8}$ & $\mathbf{5 9 2}$ & $\mathbf{5 2 6}$ & $\mathbf{4 8 2}$ & $\mathbf{5 1 3}$ & $\mathbf{5 1 2}$ & $\mathbf{5 6 6}$ & $\mathbf{5 0 3}$ \\
\hline 1 & Hidroksiurea & +2 & - & - & + & - & - & - & - & - & - & - & - & - \\
2 & $4-\mathrm{Cl} \mathrm{BBU}$ & +2 & +2 & + & + & - & + & +3 & +3 & +4 & - & + & - & - \\
3 & $4-\mathrm{Br} \mathrm{BBU}$ & + & +2 & + & + & - & + & +3 & +3 & +5 & - & + & - & - \\
4 & $4-\mathrm{F} \mathrm{BBU}$ & + & +3 & +2 & + & - & + & +3 & +3 & +5 & - & - & - & - \\
5 & $4-\mathrm{CF}_{3} \mathrm{BBU}$ & +2 & +3 & +4 & + & - & + & +3 & +3 & +3 & - & +3 & + & - \\
\hline
\end{tabular}

Keterangan: + menunjukkan interaksi yang terjadi

- menunjukkan tidak ada interaksi

Tabel 3. Nilai rerank score pada interaksi HU dan 4-X BBU terhadap 1-UWH

\begin{tabular}{|c|c|c|}
\hline No & Nama senyawa & $\begin{array}{l}\text { Rerank score (RS) } \\
\text { Kkal/mol }\end{array}$ \\
\hline 1. & $\mathrm{HU}$ & $-\quad 25,5530$ \\
\hline 2. & 4-Cl BBU & - 97,7315 \\
\hline 3. & 4-Br BBU & - 94,5985 \\
\hline 4. & 4-F BBU & - $\quad 98,9417$ \\
\hline 5. & $4-\mathrm{CF}_{3} \mathrm{BBU}$ & $-\quad 108,742$ \\
\hline
\end{tabular}

Root mean square deviation (RMSD) merupakan indikator reliabilitas dalam penambatan molekular, dimana jika nilai RMSD yang diperoleh kurang dari $2 \AA$ maka metode penambatan tersebut dikatakan baik serta memiliki nilai validitas yang tinggi [16]. Nilai RMSD diperoleh saat menambatkan senyawa uji pada reference ligand di reseptor. Pada penelitian ini nilai RMSD yang diperoleh adalah 1,003-1,598 yang berarti 
metode ini memiliki validitas yang tinggi karena nilai RMSD $<2$.

\subsection{Sintesis senyawa 4-X $B B U$}

Sintesis dilakukan melalui mekanisme substitusi nukleofilik antara benzilurea dengan benzoil klorida tersubstitusi. Hasil sintesis diuji kemurnian antara lain dengan penentuan titik leleh, dan spektrum massa. Struktur ditentukan dengan melihat spektrum dari spektrometer IR, Resonansi Magnetik Inti- ${ }^{1} \mathrm{H}$ (RMI- $\left.{ }^{1} \mathrm{H}\right)$, Resonansi Magnetik Inti- ${ }^{13} \mathrm{C}\left(\mathrm{RMI}-{ }^{13} \mathrm{C}\right)$, dan Spektrometer Massa Resolusi Tinggi (HRMS).

Persentase hasil sintesis, pengamatan organoleptis dan uji kemurnian dengan titik leleh serta KLT (eluen kloroform : etilasetat = $3: 7$ ), dapat dilihat pada Tabel 4. Data spektra HRMS dapat dilihat pada Tabel 5 .

Untuk dokumentasi identitas senyawa diperlukan spektrum Resonansi Magnetik Inti- ${ }^{1} \mathrm{H}$ (RMI- ${ }^{1} \mathrm{H}$ ) dan Resonansi Magnetik Inti- ${ }^{13} \mathrm{C}$ (RMI${ }^{13} \mathrm{C}$ ), dan dapat dengan salah satu data analisis elemental atau HRMS (High Resolution Mass Spectrometer). Satu atau lebih data spektra ini juga dapat untuk mendokumentasikan kemurnian senyawa. Nilai $[\mathrm{M}+\mathrm{H}]^{+}$yang didapat dalam rentang 0,003 $\mathrm{m} / \mathrm{z}$ dibanding nilai hasil perhitungan, menurut American Chemical Society dalam Journal of Organic Chemistry dikatakan cukup untuk mendukung penentuan struktur senyawa. Silverstein [17] memberikan batasan rentang yang lebar untuk nilai $[\mathrm{M}+\mathrm{H}]_{\text {calcd }}^{+}$dan $[\mathrm{M}+\mathrm{H}]^{+}{ }_{\text {found' }}$, yaitu 0,005 .

\subsection{Penentuan struktur senyawa $B B U$ dan 4-X BBU}

Penentuan struktur masing-masing senyawa hasil sintesis dilakukan berdasarkan data spektra Infra Merah (IR), Resonansi Magnit Inti- ${ }^{1} \mathrm{H}$ $\left(\mathrm{RMI}-{ }^{1} \mathrm{H}\right)$, Resonansi Magnit Inti- ${ }^{13} \mathrm{C}\left(\mathrm{RMI}-{ }^{13} \mathrm{C}\right)$ dan HRMS. Pada spektra IR, senyawa-senyawa menunjukkan pita absorpsi di sekitar bilangan gelombang (v) 3300 dan $3200 \mathrm{~cm}^{-1}$, ini mengarah pada vibrasi N-H. Pita absorpsi sekitar 1690 dan $1660 \mathrm{~cm}^{-1}$, mengarah pada vibrasi $\mathrm{C}=0$. Pita absorpsi sekitar 1600, 1530, dan $1430 \mathrm{~cm}^{-1}$, mengarah pada vibrasi cincin benzena.

Pada spektra $\mathrm{RMI}-{ }^{1} \mathrm{H}$, puncak di sekitar geseran kimia $(\delta)$ 9,00 ppm mengarah pada proton dari $-\mathrm{CONHCH}_{2}$ - sedang pada rentang 10,00 11,00 ppm mengarah pada proton dari -CONHCO-. Umumnya puncak-puncak tersebut pada

Tabel 4. Hasil sintesis senyawa BBU dan 4-X BBU, pengamatan organoleptis, dan uji kemurnian dengan titik leleh serta KLT

\begin{tabular}{lllll}
\hline $\mathbf{R}$ & Organoleptis & Titik leleh $\left({ }^{\circ} \mathbf{C}\right)$ & Hasil $(\%)$ & Rf \\
\hline $4-\mathrm{Cl}$ & kristal putih lembut & $86-87$ & 36 & 0,83 \\
$4-\mathrm{Br}$ & kristal putih jarum & $85-86$ & 23 & 0,41 \\
$4-\mathrm{F}$ & kristal putih jarum & $89-90$ & 3 & 0,86 \\
$4-\mathrm{CF} 3$ & kristal putih jarum & $86-87$ & 37 & 0,61 \\
\hline
\end{tabular}

* Hasil ini belum dioptimasi dan setiap percobaan hanya dilakukan satu kali

Tabel 5. Hasil analisis spektra HRMS senyawa 4-X B

\begin{tabular}{lll}
\hline HRMS (ESI-TOF) $\mathbf{m} / \mathbf{z}$ senyawa & {$[\mathbf{M}+\mathbf{H}]^{+}$Calcd } & {$[\mathbf{M}+\mathbf{H}]{ }^{+}$found } \\
\hline $4-\mathrm{Cl} \mathrm{BBU}$ & 289,0738 & 289,0747 \\
$4-\mathrm{F} \mathrm{BBU}$ & 273,1034 & 273,1032 \\
$4-\mathrm{CF}_{3} \mathrm{BBU}$ & 323,1002 & 323,1016 \\
$4-\mathrm{Br} \mathrm{BBU}$ & 333,0233 & 333,0246 \\
\hline
\end{tabular}


spektrum masing-masing senyawa berada pada rentang geseran kimia sesuai teori, kecuali pada senyawa dengan substituen bromo, puncak di luar rentang. Proton pada cincin benzena puncak terbelah karena pengaruh proton tetangga, namun umumnya puncak terbelah multiplet pada rentang 7,40-7,20 ppm. Proton pada $-\mathrm{NHC}_{2}-\mathrm{Ar}$, umumnya puncak terbelah duplet di sekitar 5,004,00 ppm.

Pada spektra $\mathrm{RMI}-{ }^{13} \mathrm{C}$, puncak di sekitar geseran kimia $(\delta)$ 155,0 ppm mengarah pada karbon dari -NHCONH-, sedangkan di sekitar rentang 166,0-175,0 ppm mengarah pada karbon dari ArCONH-. Karbon pada cincin cincin benzena, puncak umumnya berada pada rentang 138,0125,0 ppm. Puncak di sekitar 44,0 ppm umumnya ditunjukkan oleh karbon dari $\operatorname{Ar}_{\underline{C}} \mathrm{H}_{2} \mathrm{NH}-$, sementara karbon dari substituen yang mengandung karbon muncul puncak spesifik pada geseran kimia tertentu. Selisih puncak ion molekul pada $\mathrm{m} / \mathrm{z}[\mathrm{M}+\mathrm{H}]^{+}$yang didapat dari Spektra HRMS semua senyawa hasil sintesis memenuhi persyaratan lebih kecil dari 0,005 dibanding $\mathrm{m} / \mathrm{z}$ [M $+\mathrm{H}]^{+}$dari hasil perhitungan dengan menggunakan komputer progam ChemBioDraw Ultra [17], bahkan juga lebih kecil dari 0,003 m/z unit yang dipersyaratkan American Chemical Society dalam Journal of Organic Chemistry [18].

1-benzil-3-(4-fluorobenzoil)urea. Berdasarkan prosedur sintesis, didapatkan hasil 3\%, kristal putih, Rf 0,86; TL $89-90^{\circ} \mathrm{C}$. IR (KBr): $\mathrm{v}$ $1604,1545,1474,1432 \mathrm{~cm}^{-1}$ (C=C), v $3290 \mathrm{~cm}^{-1}$ $(\mathrm{NH}), \mathrm{v} 1689$ dan $1659 \mathrm{~cm}^{-1}$ (C=0), v $1272 \mathrm{~cm}^{-1}$ $(\mathrm{C}-\mathrm{N}) \cdot{ }^{1} \mathrm{H}-\mathrm{NMR}\left(\mathrm{CDCl}_{3}\right): \delta 10,36 \mathrm{ppm}(\mathrm{s}, 1 \mathrm{H}) ; \delta$ 9,25 ppm (s,1 H); $\delta$ 8,04 ppm (t,dd , $2 \mathrm{H}, \mathrm{J}=3,5$ $\mathrm{Hz}) ; \delta$ 7,349-7,276 ppm (m, $5 \mathrm{H}) ; \delta$ 7,04 ppm (t, $2 \mathrm{H}, \mathrm{J}=8,5 \mathrm{~Hz}) ; \delta 4,56 \mathrm{ppm}(\mathrm{d}, 2 \mathrm{H}, \mathrm{J}=6 \mathrm{~Hz}) \cdot{ }^{13} \mathrm{C}-$ NMR ( $\mathrm{CDCl}_{3}$ ): $\delta 138,0 ; 130,8 ; 130,7 ; 128,7 ; 128,5$; 127,$5 ; 127,3$ ppm (C6H5); $\delta$ 155,1 ppm (C=0), $\delta$ 167,4 ppm (C=0), $\delta$ 43,8 ppm (CH2). HRMS (m/z): perhitungan untuk $\mathrm{C}_{15} \mathrm{H}_{14} \mathrm{~N}_{2} \mathrm{O}_{2} \mathrm{~F}[\mathrm{M}+\mathrm{H}]^{+}$ $=273,1034$, sedangkan $[\mathrm{M}+\mathrm{H}]^{+}$didapatkan = 273,1032 . Data yang didapat dari spektra tersebut sesuai dengan identitas struktur senyawa 1-benzil-3-(4-fluorobenzoil)urea. 1-benzil-3-(4-klorobenzoil)urea. Berdasarkan prosedur sintesis, didapatkan hasil 36\%, kristal putih, Rf 0,83 ; TL $86-87^{\circ} \mathrm{C}$. IR (KBr): v 1594,1545, 1471, $1433 \mathrm{~cm}^{-1}$ (C=C), v 3466 dan $3288 \mathrm{~cm}^{-1}(\mathrm{NH}), v 1690$ dan $1661 \mathrm{~cm}^{-1}$ (C=0), v $1270 \mathrm{~cm}^{-1}(\mathrm{C}-\mathrm{N}) \cdot{ }^{1} \mathrm{H}-\mathrm{NMR}\left(\mathrm{CDCl}_{3}\right): \delta 9,95 \mathrm{ppm}(\mathrm{s}, 1$ $\mathrm{H}) ; \delta 9,17 \mathrm{ppm}(\mathrm{s}, 1 \mathrm{H}) ; \delta 7,94 \mathrm{ppm},(\mathrm{d}, 2 \mathrm{H}, \mathrm{J}=4,25$ $\mathrm{Hz}), \delta 7,39-7,27 \mathrm{ppm}(\mathrm{m}, 7 \mathrm{H}), \delta 4,58 \mathrm{ppm},(\mathrm{d}, 2 \mathrm{H}$, $\mathrm{J}=6 \mathrm{~Hz}) .{ }^{13} \mathrm{C}-\mathrm{NMR}\left(\mathrm{CDCl}_{3}\right): \delta 139,6 ; 137,9 ; 130,7$; 129,$4 ; 129,0 ; 128,7 ; 127,5 ; 127,4$ ppm (C6H5); $\delta 154,6$ ppm \& 167,3 ppm (C=0), $\delta 43,8$ ppm (-CH2). HRMS: perhitungan untuk $\mathrm{C}_{15} \mathrm{H}_{14} \mathrm{~N}_{2} \mathrm{O}_{2} \mathrm{Cl}$ $[\mathrm{M}+\mathrm{H}]^{+}=289,0738$, sedangkan $[\mathrm{M}+\mathrm{H}]^{+}$didapatkan $=289,0747$. Data yang didapat dari spektra tersebut sesuai dengan identitas struktur senyawa 1-benzil-3-(4-klorobenzoil)urea.

Senyawa 1-benzil-3-(4-bromobenzoil)urea. Berdasarkan prosedur sintesis, didapatkan hasil $23 \%$, kristal putih, Rf 0,41 ; TL $85-86^{\circ} \mathrm{C}$. IR (KBr): v 1606-1441 $\mathrm{cm}^{-1}$ (C=C), v $3010 \mathrm{~cm}^{-1} \quad(=\mathrm{C}-\mathrm{H})$, v $3384 \mathrm{~cm}^{-1}$ dan $3256 \mathrm{~cm}^{-1}(\mathrm{NH})$, v $1723 \mathrm{~cm}^{-1}$ dan $1697 \mathrm{~cm}^{-1}$ (C=0); v $2964 \mathrm{~cm}^{-1}(-\mathrm{CH} 2) .{ }^{1} \mathrm{H}-$ $\operatorname{NMR}\left(\mathrm{CDCl}_{3}\right): \delta 8,65 \mathrm{ppm}(\mathrm{s}, 1 \mathrm{H}, \mathrm{br}) ; \delta 5,65 \mathrm{ppm}$ (s,1H,br); $\delta 7,48$ ppm (d, $2 \mathrm{H}, \mathrm{J}=8,5 \mathrm{~Hz}), \delta 7,28$ $7,21 \mathrm{ppm}(\mathrm{m}, 3 \mathrm{H}), \delta 7,15 \mathrm{ppm}(\mathrm{d}, 2 \mathrm{H}, \mathrm{J}=8,5 \mathrm{~Hz})$, $\delta 6,99 \mathrm{ppm}(\mathrm{d}, 2 \mathrm{H}, \mathrm{J}=7 \mathrm{~Hz}) ; \delta 4,94 \mathrm{ppm},(\mathrm{s}, 2 \mathrm{H})$. ${ }^{13} \mathrm{C}$-NMR $\left(\mathrm{CDCl}_{3}\right): \delta 137,4 ; 134,7 ; 131,7 ; 128,7$; 127,$9 ; 127,4 ; 126,4 ; 125,2$ ppm (C6H5); $\delta 155,3$ ppm (C=0), $\delta$ 174,2 ppm (C=0), $\delta$ 49,7 ppm (CH2). HRMS: perhitungan untuk $\mathrm{C}_{15} \mathrm{H}_{14} \mathrm{~N}_{2} \mathrm{O}_{2} \mathrm{Br}$ $[\mathrm{M}+\mathrm{H}]^{+}=333,0233$ sedangkan $[\mathrm{M}+\mathrm{H}]^{+}$didapatkan $=333,0246$. Data yang didapat dari spektra tersebut sesuai dengan identitas struktur senyawa 1-benzil-3-(4-bromobenzoil) urea.

\section{1-benzil-3-(4-trifluorometilbenzoil)urea.}

Berdasarkan prosedur sintesis, didapatkan hasil $37 \%$, kristal putih, Rf 0,61; TL $86-87^{\circ} \mathrm{C}$. IR (KBr): v 1551-1422 $\mathrm{cm}^{-1}$ (C=C), v $3088 \mathrm{~cm}^{-1} \quad(=\mathrm{C}-\mathrm{H})$, v $3329 \mathrm{~cm}^{-1}(\mathrm{NH}), v 3253 \mathrm{~cm}^{-1}(\mathrm{NH}), v 1689 \mathrm{~cm}^{-1}$ dan $1668 \mathrm{~cm}^{-1} \quad(\mathrm{C}=0), \mathrm{v} 2948 \mathrm{~cm}^{-1}(\mathrm{CH} 2) .{ }^{1} \mathrm{H}-$ $\operatorname{NMR}\left(\mathrm{CDCl}_{3}\right): \delta 10,84 \mathrm{ppm}(\mathrm{s}, 1 \mathrm{H}, \mathrm{br}) ; \delta 9,28 \mathrm{ppm}$ (s, 1H, br); $\delta 8,13$ ppm (d, $2 \mathrm{H}, \mathrm{J}=8 \mathrm{~Hz}) ; \delta 7,58 \mathrm{ppm}$ (d, $2 \mathrm{H}, \mathrm{J}=8,5 \mathrm{~Hz}) ; \delta$ 7,36-7,27 ppm (m, 5H); $\delta 4,57$ ppm, (d, $2 \mathrm{H}, \mathrm{J}=6 \mathrm{~Hz}) \cdot{ }^{13} \mathrm{C}-\mathrm{NMR}\left(\mathrm{CDCl}_{3}\right): \delta 128,8$; 128,$7 ; 127,6 ; 127,2 ; 126,8 ; 125,6 ; 125,5$ ppm 
(C6H5); $\delta 124,6$ ppm (CF3); $\delta 155,4$ ppm (C=0), $\delta$ 167,5 ppm (C=0), $\delta 43,8$ ppm (CH2). HRMS: perhitungan untuk $\mathrm{C}_{16} \mathrm{H}_{14} \mathrm{~N}_{2} \mathrm{O}_{2} \mathrm{~F}_{3}[\mathrm{M}+\mathrm{H}]^{+}=323,1002$, sedangkan $[\mathrm{M}+\mathrm{H}]^{+}$didapatkan $=323,1016$. Data yang didapat dari spektra tersebut sesuai dengan identitas struktur senyawa 1-benzil-3-(4-trifluorometilbenzoil)urea.

\subsection{Uji aktivitas in-vitro pada sel kanker MCF-7}

Dengan mamasukkan dan mengolah data persentase sel mati dari berbagai konsentrasi masing-masing senyawa menggunakan analisis probit pada SPSS, didapatkan $\mathrm{IC}_{50}$ senyawa $\mathrm{HU}$ dan 4-X BBU, seperti yang dapat dilihat pada Tabel 6.

Tabel 6. Nilai rerank score pada interaksi HU dan 4-X BBU terhadap 1-UWH

\begin{tabular}{cll}
\hline No & Senyawa & $\mathbf{I C}_{\mathbf{5 0}}(\boldsymbol{\mu M})$ \\
\hline 1. & $\mathrm{HU}$ & 1228,96 \\
2. & $4-\mathrm{Cl} \mathrm{BBU}$ & 3171,36 \\
3. & $4-\mathrm{Br} \mathrm{BBU}$ & 374,08 \\
4. & $4-\mathrm{F} \mathrm{BBU}$ & 314,92 \\
5. & $4-\mathrm{CF}_{3} \mathrm{BBU}$ & 215,70 \\
\hline
\end{tabular}

$\mathrm{IC}_{50}$ dari senyawa $\mathrm{HU}=1228,96 \mu \mathrm{M}$ lebih besar dibanding 4-Br, 4-F, 4- $\mathrm{CF}_{3}$ BBU yang $\mathrm{IC}_{50}$ nya berkisar $215,70-374,08 \mu \mathrm{M}$, berarti untuk dapat menghambat $50 \%$ proliferasi sel MCF-7, senyawa BBU tersubstitusi butuh konsentrasi yang lebih kecil yaitu berkisar 17,55-30,44\% dibanding senyawa pembanding HU. Dengan kata lain aktivitas senyawa hasil modifikasi struktur dengan pendekatan lipofilik dan elektronik terbukti meningkat aktivitasnya dibanding senyawa pembanding HU. Bila dibandingkan dengan hasil uji in silico di mana semua senyawa BBU tersubstitusi diprediksi aktivitasnya lebih tinggi dibanding BBU, maka ada korelasi yang kurang proporsional antara uji in silico dan uji in vitro. Senyawa 4-Cl BBU aktivitasnya paling rendah yaitu $\mathrm{IC}_{50}=$ $3171,36 \mu \mathrm{M}$. Atom $\mathrm{Cl}$ pada posisi para mempunyai nilai $\pi(0,70)$ dan $\sigma(0,23)$ positif, interpretasi yang sederhana adalah peningkatan aktivitas disebabkan oleh peningkatan sifat lipofilik dan elektronik, namun hasil yang didapatkan tidak demikian. Hal ini mungkin terjadi karena karena ada faktor yang berpengaruh sepanjang proses obat melarut dan menembus membran biologis sampai menimbulkan aktivitas. Uji in silico hanya mempertimbangkan sifat elektronik dan sterik tanpa mempertimbangkan sifat lipofilik. Penyebab rendahnya aktivitas 4-Cl BBU secara teoritis belum dapat dijelaskan oleh karena substituen halogen yang lain pada posisi yang sama terbukti mempunyai aktivitas, sehingga perlu studi lebih lanjut untuk mencari jawabannya. Urutan aktivitas lebih tinggi dibanding $\mathrm{HU}$ sebagai berikut $4-\mathrm{CF}_{3} \mathrm{BBU}>4-\mathrm{F} \mathrm{BBU}>4$-Br BBU. Trifluorometil $\left(-\mathrm{CF}_{3}\right)$ terdiri dari 3 gugus fluoro $(-\mathrm{F})$ yaitu sebuah senyawa halogen yang memiliki sifat penarik elektron terbesar melalui efek induksi negatif (I-). Selain efek induksi negatif, gugus trifluorometil juga memiliki efek konjugasi (R-). Gugus dengan sifat penarik elektron dapat meningkatkan aktivitas dengan meningkatkan kestabilan interaksi obat dengan reseptor dan menurunkan kerapatan antar elektron sehingga mempengaruhi kemudahan dan lama durasi senyawa berikatan dengan reseptor [19]. Urutan keelektronegatifan paling besar $\mathrm{F}$, elektronegativitas $=4$, apalagi $\mathrm{CF}_{3}$, mengandung 3 atom $\mathrm{F}$, ditunjang dengan urutan ukuran atom $\mathrm{F}$ paling kecil sehingga tidak merupakan halangan ruang saat akan terjadi interaksi $0-R$, aktivitas akan meningkat. Nilai $\pi(0,88)$ dan $\sigma(0,54)$ gugus $-\mathrm{CF}_{3}$ pada posisi para, menunjang peningkatan aktivitas dibandingkan atom -F pada posisi para nilai $\pi(0,14)$ dan $\sigma(0,06)$, demikian juga atom -Br pada posisi para $\pi(0,86)$ dan $\sigma(0,23)$ (Taylor,1993).

\section{Kesimpulan}

Senyawa 1-benzil-3-(4- $\mathrm{CF}_{3}$-benzoil)urea lebih poten dibandingkan yang lain berdasarkan nilai RS paling kecil pada uji in-silico (-108,742 kkal/ mol) dan $\mathrm{IC}_{50}$ juga paling kecil pada uji in-vitro yaitu 215,70 $\mu \mathrm{M}$. Sangat direkomendasikan untuk dilakukan prediksi bioavailabilitas dan tok- 
sisitas serta uji lebih lanjut senyawa 1-benzil3 -(4- $\mathrm{CF}_{3}$-benzoil)urea sebagai calon obat dengan aktivitas antiproliferatif.

\section{Ucapan Terimakasih}

Ucapan terima kasih disampaikan kepada Fakultas Farmasi Universitas Surabaya, Fakultas Farmasi Universitas Airlangga, dan Fakultas Kedokteran Universitas Gadjah Mada serta Departemen Kimia Institut Teknologi Bandung atas semua dukungan yang diberikan selama penelitian ini.

\section{Daftar pustaka}

1. Suhud F, Siswandono, Budiati T. Synthesis and Activity Evaluation of a Novel Lead Compound 1-Benzyl-3-Benzoylurea as Antiproliferative Agent. World Journal of Pharmaceutical Sciences. 2015;3(2): 192-5.

2. Thomsen R, Christensen MH. MolDock: A New Technique for High-Accuracy Molecular Docking, Journal of Medicinal Chemistry. 2006;49(11): 3315-21.

3. Hinchliffe A. Molecular Modelling for Beginners. $2^{\text {nd }}$ ed. Oxford: John Willey \& Sons Ltd. 2008:81-93.

4. Martin YC. Quantitative of Drug Design, Critical Introduction. $2^{\text {nd }}$ ed, New York: Marcel Dekker Inc. 2010:1-11, 49-57.

5. Beale JM, Block JH. eds. Wilson and Gisvolds Textbook of Organic Medicinal and Pharmaceutical Chemistry. ${ }^{12}$ th ed. Philadelphia: Lippincott Williams \& Wilkins. 2011:17-41.

6. Siswandono, Soekardjo B. Kimia Medisinal. Surabaya: Airlangga University Press. 2000:304-7, 313-54.

7. Li H-Q, Zhu T-T, Yan T, Luo Y, Zhu H-L. Design, synthesis, and structure-activity relationships of antiproliferative 1,3-disubstituted urea derivatives. Eur. J. Med. Chem. 2009(44): 453-9.

8. Lokwani D, Bhandari S, Pujar R, Shastri P, Shelke G, Pawar V. Use of Quantitative Structure-Activity Re- lationship (QSAR) and ADMET prediction studies as screening methods for design of benzylurea derivatives for anti-cancer activity. J. Enzyme Inhib. Med. Chem. 2011;26(3):319-31.

9. Hardjono S. Modifikasi struktur 1-(benzoiloksi) urea dan Hubungan Kuantitatif Struktur-Aktivitas Sitotoksiknya. Disertasi, Program Doktor Fakultas Sains dan Teknologi, Universitas Airlangga, Surabaya; 2012.

10. Clayden J, Greeves S, Warren N, Wothers P. Organic Chemistry. New York: Oxford University Press. 2001:279-303.

11. Jensen F. Introduction to Computational Chemistry. $2^{\text {nd }}$ ed, Chichester: John Willey \& Sons Ltd. 2007:415-6.

12. El-Sawy E, Mandour A, Mahmoud K, Islam I-E, Salem HMA. Synthesis antimicrobial and anticancer activities of some new N-ethyl, N-benzyl and N-benzoyl-3-indolyl heterocycles. Acta Pharm. 2012;62:157-79.

13. Dwitaharyani, Milannisa. Nanopropolis sebagai Penghambat Proliferasi Sel Kanker Payudara MCF-7. Departemen Biokimia FMIPA ITB, Bogor. 2012:1. http://repository.ipb.ac.id/ handle/123456789/54708. Diunduh 2/5/2013.

14. Ued JY, Tezuka Y, Banskota AH, Tran QL, Tran QK, Harimaya Y, Saiki I, Kadota S. Antiproliferatif Activity of Vietnamese Medicine Plants. Biol. Pharm. Bull. 2002;25(6):753-60.

15. Manual Software Molegro Virtual Docker, 2010; http://www.molegro/mvd- technology.php. Diunduh 19/8/2013.

16. Zukhrullah. Kajian Beberapa Senyawa Antiinflamasi: Penambatan terhadap Siklooksigenase-2 Secara In Silico. Majalah Farmasi dan Farmakologi. 2012;16(1):37-44.

17. Silverstein RM, Webster FX, Kiemle DJ. Spectrometric Identification of Organic Compounds. $7^{\text {th }} \mathrm{ed} \mathrm{.}$ USA: John Wiley \& Sons; 2005:4

18. Journal of Organic Chemistry http:// www.pubs. acs.org/joceah/submission/acc.html Diunduh 2/ $5 / 2013$

19. Thomas G. Fundamental of Medicinal Chemistry. John Wiley \& Sons Ltd, England; 2003. 